\title{
Sample numbers for microhistological estimation of fecal vizcacha diets
}

\author{
ELIANA E. BONTTI AND ROBERTO M. BÓO
}

Authors are Assistant and Research Technician, Departamento de Biología and Comisión de Investigaciones Científicas (CIC); Professor and Researcher, Departamento de Agronomía (UNS) and Comisión de Investigaciones Científicas (CIC). Centro de Recursos Naturales Renovables de la Zona Semiárida (CERZOS). Avenida San Andrés 800 (8000) Bahía Blanca, Argentina.

\begin{abstract}
Precise estimates of diet composition are useful to assess herbivores impact on rangelands and to make management decisions. Since the variability within- and between-samples affect precision of estimates on diet studies, we studied this variability in diets of the rodent vizcacha (Lagostomus maximus Blainv.). We analyzed fecal pellets using a microhistological technique and we estimated the number of samples and subsamples required to achieve given confidence levels. Diets of this herbivore, which is thought to compete with cattle for forage, were studied in November 1994, May, July, and October 1995 in a mixed shrubgrassland community of the southern Caldenal in central Argentina. Most grasses, the main components of the diets (> $80 \%$ ), were estimated with high precision (confidence interval: $\mathrm{CI}=10 \%, \mathrm{p}=0.05$ ) by observing 14 samples and 5 slides per sample. Forbs (5-6\%) and shrubs (12\%) were estimated with this same number of samples and slides, but yielded a lower level of precision $(\mathrm{CI}=\mathbf{2 0 \%}, \mathrm{p}=\mathbf{0 . 1 0}$ ). Although our results may not be directly applicable to other vegetation or herbivores, the procedures may be used in other situations to improve precision of diet estimates through microhistological analysis of feces.
\end{abstract}

Key Words: diet selection, precision, Lagostomus maximus, central Argentina, Caldenal.

When assessing food habits or effects of herbivores on the environment, it is important to obtain accurate measures of diet selection. The Sparks and Malechek (1968) technique has been frequently used to estimate diet botanical composition, although some factors affect its precision. Overestimation may arise from excessive fragmentation during slide preparation (Dearden et al. 1975), from a high ratio of identifiable/non-identifiable fragments (Havstad and Donart 1978), and from other factors that increase identification probability (Holechek and Gross 1982). Underestimation may also occur due to high digestibility of some taxa (Vavra and Holechek 1980, Holechek et al. 1982), due to low-identifiable/non-identifiable fragments ratio, and due to low degree of fragmentation during slide preparation.

One major factor to consider in diet studies is the number of

We would like to thank H. Canessa, F. Zanetti, I. Lindström and O. Elía for invaluable assistance. Research was funded by Consejo Nacional de Investigaciones Científicas y Técnicas (CONICET), Universidad Nacional del Sur (UNS), Comisión de Investigaciones Científicas (CIC) and Agencia Nacional de Promoción Científica y Tecnológica.

Manuscript accepted 30 Nov. 01

\section{Resumen}

Estimaciones precisas de la composición de dietas son útiles para determinar el impacto de los herbívoros en los pastizales naturales y tomar decisiones de manejo. Debido a que la variabilidad dentro de una muestra y entre muestras puede afectar la precisión de las estimaciones en los estudios de dieta, nosotros estudiamos esta variabilidad en las dietas del roedor vizcacha (Lagostomus maximus Blainv.). Analizamos pellets fecales empleando una técnica microhistológica y estimamos el número de muestras y submuestras requeridos para alcanzar determinados niveles de precisión. La dieta de estos herbívoros, que son considerados competidores de los vacunos por el forraje, se estudió en noviembre de 1994, mayo, julio y octubre de 1995 en una comunidad mixta de arbustal y pastizal en el sur del Caldenal en Argentina central. La mayoría de las gramíneas, componentes principales de las dietas $(>\mathbf{8 0} \%)$, fueron estimadas con alta precisión (intervalo de confianza: $\mathrm{IC}=10 \%, \mathrm{p}=\mathbf{0 , 0 5 \%}$ ) observando 14 muestras y 5 preparados por muestra. Las dicotiledóneas herbáceas anuales $(5-6 \%)$ y arbustos (12\%) fueron estimados con este mismo número de muestras y preparados pero alcanzando menor nivel de precisión (IC $=20 \%, p=0,10 \%$ ). Si bien nuestros resultados no son directamente aplicables a otros tipos de vegetación o herbívoros, los procedimientos pueden ser usados en otras situaciones para mejorar la precisión en la estimación de dietas a través del análisis microhistológico de heces.

samples needed to obtain a desired level of precision for estimates. This has been studied with esophageal samples (Harniss et al. 1975, Brizuela et al. 1983) and with fecal samples (Bóo et al. 1991) from domestic livestock. Reports of such studies for wild herbivores were not detected. Variability in the estimation of diet components within samples will affect variability between samples. If low precision is achieved in within-sample mean estimates, low precision in the estimation of sample means may be expected, which in turn will increase the number of samples to estimate the population parameter for a given level of precision.

The objectives of this work were: 1) To study within- and between-sample variability on estimates of different components of vizcacha diets and 2) To calculate the number of samples per date and sub-samples per sample required for defined levels of precision when estimating vizcacha dietary composition.

\section{Study area and methods}

The study was conducted in a 600 ha pasture located in southeast La Pampa, Argentina ( $\left.38^{\circ} 45^{\prime} \mathrm{S}, 63^{\circ} 45^{\prime} \mathrm{W}\right)$. Mean annual rain- 
fall is $448 \mathrm{~mm}$ with about $60 \%$ occurring in spring and fall. Rainfall during the study was $21.0 \mathrm{~mm}$ in November 1994, $2.8 \mathrm{~mm}$ in May 1995, $4.8 \mathrm{~mm}$ in July 1995 , and 4.2 in October 1995. These values were below historical records for the same months $(26,16,28$, and $30 \mathrm{~mm}$ respectively). Due to this drought, annual forbs were scarce in the area (1.1-2.9\% cover, Bontti et al. 1999) where they were usually abundant during wet springs.

Mean annual potential evapotranspiration is $800 \mathrm{~mm}$ (Peláez 1986), mean annual temperature is $15.3^{\circ} \mathrm{C}$ with a minimum mean of $7^{\circ} \mathrm{C}$ in July and a maximum mean of $23.6^{\circ} \mathrm{C}$ in January. Recorded maximum and minimum temperatures are $42.5^{\circ} \mathrm{C}$ and $-12.8^{\circ} \mathrm{C}$ respectively.

Vegetation is characterized by woody species dominance and a rich herbaceous layer. Woody cover varies between 50 to $70 \%$ with caldén (Prosopis caldenia Burk.), algarrobo (P. flexuosa D. C.) and piquillín (Condalia microphylla Cav.) as the most abundant (Bóo and Peláez 1991). The herbaceous cover is $40-50 \%$ and is dominated by perennial cool season bunchgrasses such as flechilla negra (Piptochaetium napostaense (Speg.) Hack.) and flechilla fina (Stipa tenuis Phil.). Coirón (S. speciosa Trin. et Rupr.) and flechilla blanca (S. gynerioides Phil.) are abundant, and flechilla alta (S. clarazii Phil.), coirón-poa (Poa ligularis Nees), and cola de zorro (Pappophorum mucronulatum Nees) are less abundant (Bóo and Peláez 1991). Flechilla alta and coirón-poa, once abundant in pristine vegetation, were replaced by flechilla negra and flechilla fina under moderate continuous grazing (Distel and Bóo 1995). Bare ground (30-40\%) is colonized during wet years by annual forbs, mostly carretilla (Medicago minima (L.) Grufberg) and alfilerillo (Erodium cicutarium L'Herit, (Bóo and Peláez 1991)). Annual above ground net primary production in this plant community was $862 \mathrm{~kg} \mathrm{ha}^{-1}$, and 684 $\mathrm{kg} \mathrm{ha}^{-1}$ for flechilla fina and flechilla negra respectively in a year with $532 \mathrm{~mm}$ of rainfall (Distel and Fernández 1986, Distel 1987).

Twenty vizcacha colonies per date were sampled by collecting 1 group of fresh fecal pellets from each colony. Colonies were 200 to $500 \mathrm{~m}$ from one another and within the same pasture. The vegetation was homogeneous in the area under their influence. Further details regarding the study site are given by Bontti et al. (1999).

Fecal samples were dried at $60^{\circ} \mathrm{C}$ for 48 hours, ground through a $1 \mathrm{~mm}$ mesh, in preparation of microhistological analysis.
Modified Sparks and Malechek (1968) techniques were employed converting plant frequency in microscope fields to density. Hertwig's solution was not used and 40 fields per slide were observed. Each group of fecal pellets was considered a sample and microscopic slides from 1 sample were considered subsamples.

To study variability within a sample, 20 slides from a single sample per date were prepared and 40 microscope fields per slide were observed using $100 \mathrm{X}$ magnification for a total of 800 fields. To estimate variability between samples we used 20 samples per date with 5 slides per sample and 40 fields per slide generating a total of 200 fields per sample. Fragments were identified by comparing fecal material with a reference collection including all major species in the area (Lindström 1994, Lindström et al. 1998a, Lindström et al. 1998b).

The number of slides per sample and the number of samples for given confidence intervals were estimated using Snedecor's equation (1956):

$$
\mathrm{n}=\mathrm{t}^{2} \mathrm{CV}^{2} / \mathrm{d}^{2}
$$

where $\mathrm{n}$ is the number of samples, $\mathrm{t}$ is the tabulated Student's $t$ value for a given error probability (in this study: $\mathrm{p}=0.05$ or

Table 1. Mean percentage $(\overline{\mathbf{x}})$ of major vizcacha diet components ${ }^{1}$ describing within- sample variation; coefficients of variation, and number of subsamples (rounded values) required for 95 and 90\% probability levels (p), and 10 and $20 \%$ confidence intervals (CI) in central Argentina from 1994 to 1995.

\begin{tabular}{|c|c|c|c|c|c|c|}
\hline \multirow[b]{3}{*}{ Date and species } & \multirow[b]{3}{*}{$\overline{\mathbf{x}}$} & \multirow[b]{3}{*}{ C.V. } & \multicolumn{4}{|c|}{ Number of subsamples } \\
\hline & & & \multicolumn{2}{|c|}{$p=0.05$} & \multicolumn{2}{|c|}{$p=0.10$} \\
\hline & & & $10 \% \mathrm{CI}$ & $20 \% \mathrm{CI}$ & $10 \% \mathrm{CI}$ & $20 \% \mathrm{CI}$ \\
\hline November 1994 & $(\%)$ & $\cdots$ & $\cdots$ & - (No.) - - & $\cdots$ & $-\cdots$ \\
\hline \multicolumn{7}{|l|}{ Grasses } \\
\hline Flechilla negra & 67.8 & 4.4 & 1 & 1 & 1 & 1 \\
\hline Flechilla fina & 9.5 & 6.0 & 2 & 1 & 2 & 1 \\
\hline Coirón & 5.4 & 7.1 & 3 & 1 & 2 & 1 \\
\hline \multicolumn{7}{|l|}{ Forbs } \\
\hline Alfilerillo & 5.1 & 8.5 & 4 & 1 & 3 & 1 \\
\hline Carretilla & 4.7 & 9.6 & 5 & 1 & 3 & 1 \\
\hline \multicolumn{7}{|l|}{ May 1995} \\
\hline \multicolumn{7}{|l|}{ Grasses } \\
\hline Flechilla negra & 62.1 & 8.6 & 2 & 1 & 2 & 1 \\
\hline Flechilla fina & 27.1 & 12.7 & 3 & 1 & 2 & 1 \\
\hline \multicolumn{7}{|l|}{ July 1995} \\
\hline \multicolumn{7}{|l|}{ Grasses } \\
\hline Flechilla negra & 52.4 & 6.9 & 1 & 1 & 1 & 1 \\
\hline Flechilla fina & 19.6 & 13 & 3 & 1 & 2 & 1 \\
\hline Coirón & 10.6 & 26.6 & 9 & 3 & 6 & 2 \\
\hline \multicolumn{7}{|l|}{ Shrubs } \\
\hline Piquillín & 12.1 & 24.7 & 8 & 2 & 5 & 2 \\
\hline \multicolumn{7}{|l|}{ October 1995} \\
\hline \multicolumn{7}{|l|}{ Grasses } \\
\hline Flechilla negra & 49.3 & 8.4 & 2 & 1 & 1 & 1 \\
\hline Flechilla fina & 19.8 & 16.8 & 4 & 1 & 3 & 1 \\
\hline Coirón & 17.8 & 22.5 & 7 & 2 & 5 & 2 \\
\hline
\end{tabular}

${ }^{1}$ Plant species contributing $<4 \%$ of the total diet were excluded. $p=0.10)$ and degrees of freedom of the sample, C.V. is the coefficient of variation and $\mathrm{d}$ is the half-width of the desired confidence interval expressed as a percent of the sample mean. In this study $\mathrm{n}$ was calculated using desired confidence intervals (CI) of 10 and $20 \%$ of the mean. Arcsine transformation (degrees) of the mean percentage of each component was calculated prior to statistical analysis. This transformation is recommended when data expressed as percentages that lie outside the 30-70\% range (Snedecor and Cochran 1980).

\section{Results and Discussion}

\section{Variability within samples}

Grasses were main contributors to the diets throughout the study (Tables 1 and 2). Considering all sampling dates, high precision $(\mathrm{CI}=10 \%, \mathrm{p}=0.05)$ in the estimation of flechilla negra and flechilla fina could be achieved by observing up to 3 slides (Table 1). Three to 9 slides were needed to obtain best estimates $(\mathrm{CI}=10 \%$, $\mathrm{p}=0.05$ ) of coirón. Analyzing 7 to 9 slides per sample would be very time consuming, especially when a high number of samples must be quantified (i.e. monthly). 
Thus, it would be possible to estimate the contribution of coirón with 3 slides in July and with 2 slides in October, but with a lower level of precision $(\mathrm{CI}=20 \%, \mathrm{p}=$ 0.05 ) in both months.

Only low amounts of 2 forbs, carretilla and alfilerillo were detected in fecal samples in November 1994 (Table 1). Both could be estimated with high levels of precision $(\mathrm{CI}=10 \%, \mathrm{p}=0.05)$ by observing 5 slides. Even though forbs are usually underestimated by fecal microhistological analysis, they were very scarce in the field due to the drought, and we believe that consumption was low. In the case of carretilla, most of the material on the ground were pods from the previous growing season.

Piquillín was the only woody species found in vizcacha diets. Again, the high number of slides necessary to achieve a high level of precision $(\mathrm{CI}=10 \%, \mathrm{p}=$ 0.05 ) for this species would be too time consuming, but an acceptable level of precision $(C I=20 \%, p=0.05)$ could be achieved analyzing 2 slides (Table 1 ).

Considering all sampling dates and species, $\leq 5$ slides would be adequate to estimate some species (i.e. flechilla negra, flechilla fina, alfilerillo and carretilla) with good precision $(\mathrm{CI}=10 \%, \mathrm{p}=0.05)$, whereas $\leq 5$ slides for other species with small contribution to the diets such as coirón and piquillín would be adequate for a lower level of precision $(\mathrm{CI}=20 \%, \mathrm{p}=0.05)$.

\section{Variability between samples}

Flechilla negra and flechilla fina were the bulk of vizcacha diets throughout the study (Table 2). Considering all dates, these species can be estimated with the highest precision $(\mathrm{CI}=10 \%, \mathrm{p}=0.05)$ analyzing $\leq 6$ samples. Ten samples would be necessary to obtain the same precision with coirón (in October), a grass that was consistently less abundant in the diets for all dates.

Forbs (i.e. alfilerillo and carretilla) were detected only in low percentages in November 1994 and October 1995 (Table 2). Analyzing 18 samples provided a good estimation $(\mathrm{CI}=10 \%, \mathrm{p}=0.05)$ in November and a less precise estimation $(\mathrm{CI}=20 \%, \mathrm{p}=0.05)$ in October. The analysis of 12 samples would yield the lowest precision $(\mathrm{CI}=20 \%, \mathrm{p}=0.10)$, but this could be an acceptable estimate considering the low contribution of forbs ( 5 and $6 \%$ ) to vizcacha diets.

Piquillín, the only woody species present in the diets (Table 2, July), showed high variability $(\mathrm{CV}=70 \%)$. Twenty samples would give an estimate within $20 \%$ of the mean $(\mathrm{p}=0.05)$, but this number would be too costly for long-term studies.

The number of samples analyzed in a long-term study depends on inherent variability of the samples, the objective of the study, and available resources. Considering that resources are usually limiting, analyzing 14 samples per date would give precise estimation $(\mathrm{CI}=10 \%, \mathrm{p}=0.05)$ of the major components (i.e. grasses). However, minor components such as forbs and woody species would be estimated with low precision. In our experience, a trained operator would need about $90 \mathrm{~min}$ utes to process 5 slides from 1 sample while observing 40 fields per slide ( $\$ 7.5$ labor, \$ 2.5 materials).

Considering between samples analysis, precision in this work was higher than reported in studies by Harniss et al. (1975) and Brizuela et al. (1983). This may be due to 2 reasons. First, the cited studies used fistulated animals which restricted the number of available samples and expanded confidence intervals and second, 40 microscope fields per slide were observed in this study as compared to 20 observed fields in the studies mentioned above. A larger number of observations may contribute to smaller variances and coefficients of variation but would also increase the cost of the analysis.

Table 2. Mean percentage $(\overline{\mathbf{x}})$ of major vizcacha diet components ${ }^{1}$ describing between-sample variation; coefficients of variation, and number of colonies sampled (rounded values) required for 95 or $90 \%$ probability levels (p), and 10 and $20 \%$ confidence intervals (CI) in central Argentina from 1994 to 1995.

\begin{tabular}{|c|c|c|c|c|c|c|}
\hline \multirow[b]{3}{*}{ Date and species } & \multirow[b]{3}{*}{$\overline{\mathrm{x}}$} & \multirow[b]{3}{*}{ C.V. } & \multicolumn{4}{|c|}{ Number of colonies } \\
\hline & & & \multicolumn{2}{|c|}{$p=0.05$} & \multicolumn{2}{|c|}{$p=0.10$} \\
\hline & & & $10 \% \mathrm{CI}$ & $20 \% \mathrm{CI}$ & $10 \% \mathrm{CI}$ & $20 \% \mathrm{CI}$ \\
\hline November 1994 & $(\%)$ & 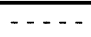 & $\ldots \ldots$ & - (No.) - - & $\ldots \ldots$ & $\overline{--1 .-}$ \\
\hline \multicolumn{7}{|l|}{ Grasses } \\
\hline Flechilla negra & 69.4 & 3. & 1 & 1 & 1 & 1 \\
\hline Flechilla fina & 10.3 & 8.0 & 1 & 1 & 1 & 1 \\
\hline Coirón & 4.9 & 27.0 & 5 & 2 & 4 & 1 \\
\hline \multicolumn{7}{|l|}{ Forbs } \\
\hline Alfilerillo & 6.0 & 47.0 & 18 & 5 & 13 & 3 \\
\hline \multicolumn{7}{|l|}{ May 1995} \\
\hline \multicolumn{7}{|l|}{ Grasses } \\
\hline Flechilla negra & 70.2 & 22 & 2 & 1 & 2 & 1 \\
\hline Flechilla fina & 23.4 & 27 & 4 & 1 & 3 & 1 \\
\hline \multicolumn{7}{|l|}{ July 1995} \\
\hline \multicolumn{7}{|l|}{ Grasses } \\
\hline Flechilla negra & 44.9 & 22 & 5 & 1 & 3 & 1 \\
\hline Flechilla fina & 22.3 & 20 & 5 & 2 & 3 & 1 \\
\hline Coirón & 12.1 & 32 & 7 & 2 & 5 & 2 \\
\hline \multicolumn{7}{|l|}{$\underline{\text { Shrubs }}$} \\
\hline Piquillín & 12.2 & 70 & 77 & 20 & 53 & 14 \\
\hline \multicolumn{7}{|l|}{ October 1995} \\
\hline \multicolumn{7}{|l|}{ Grasses } \\
\hline Flechilla negra & 44.3 & 22 & 5 & 2 & 3 & 1 \\
\hline Flechilla fina & 24.9 & 23 & 6 & 2 & 5 & 1 \\
\hline Coirón & 15.3 & 31 & 10 & 3 & 7 & 2 \\
\hline Forbs & & & & & & \\
\hline Carretilla & 5.0 & 95 & 71 & 18 & 49 & 12 \\
\hline
\end{tabular}

Plant species contributing $<4 \%$ of the total diet were excluded

\section{Comparison of variability within- and between samples} gives precise estimates for species with low within- between-sample coefficients of variation (Tables 1 and 2). In general, major increases in sample size occurred when dietary components were below $10 \%$ (Tables 1 and 2).

Even though in November 1994 the within-sample coefficient of variation for forbs was slightly higher than for grasses, the between-sample coefficient of variation for alfilerrillo was dramatically higher than for grasses. This suggests that high digestibility, characteristic of many forbs, may cause underestimation of alfilerillo in microhistological analyses of fecal samples (Vavra and Holechek 1980, Holechek et al. 1982). In addition, when forbs are scarce in the ingesta, high digestibility could cause disappearance or errors in the detection of fragments and a consequent increase in the sample variance.

A different situation may have occurred with carretilla, where the leaves have structures (i.e. calcium oxalate crystals) that allow easy identification (Lindström 1994). However, due to the pronounced drought during the study, most of the carretilla consumed by vizcachas were fruits
As expected, low number of samples 
or parts of fruits from the previous growing cycle. These materials were difficult to identify and this could partially explain the high CV that we found in October 1995 (Table 2).

In July 1995 the within-sample coefficient of variation for piquillín was similar to coirón (Table 1), but the between-sample coefficient of variation for the shrub was twice higher than for coirón (Table 2). Piquillín, in spite of being abundant in the field, only appeared in diets when forage resources were very scarce (Bontti et al. 1999). Consumption of piquillín by some animals was often erratic, causing a high sample variance. Shrubs are difficult to estimate when a high stem/leaf proportion is present in the diet (Holechek and Valdez 1985) and this can also explain the high between-sample variance. These results indicate that microhistological analysis of feces may be most appropriate when the bulk of the diets are grasses rather than forbs or shrubs.

Our results indicate that this procedure may be adapted for specific vegetation and herbivore type in other studies. This methodology could also be used to evaluate the technique at different phenological types or when the plant community changes in response to specific climatic conditions. For example, annual forbs consumption may be difficult to determine because of their high digestibility, but their abundance in the plant community usually depends on average or above average rains during the spring. When such situations occur, additional samples may be collected at specific sampling dates to estimate forbs with a desired level of precision.

\section{Literature Cited}

Bontti, E. E., R. M. Bóo, L. I. Lindström, and O. R. Elia. 1999. Botanical composition of cattle and vizcacha diets in central Argentina. J. Range Manage. 52(4):370-377.

Bóo, R. M. and D. V. Peláez. 1991. Ordenamiento y clasificación de la vegetación en un área del sur del Distrito del Caldén.(In Spanish). Bol. Soc. Argent. Bot. 27:135-141.

Bóo, R., L. Lindström, and E. Lutz. 1991. Número de preparados por muestra y número de muestras en la estimación de la composición botánica de heces de vacunos. (In Spanish). Rev. Arg. Prod. Anim. 11:13-18.

Brizuela, M. A., M. S. Cid, M. A. Cauhépé, E. M. Viviani Rossi, and C. Yagguedu. 1983. Estimación de la composición botánica de la dieta de vacunos en un pastizal natural. I. Número de muestras requerido.(In Spanish) Prod. Anim. 10: 385-394.
Dearden, B. L., R. E. Pegau, and R. M. Hansen. 1975. Precision of microhistological estimates of ruminant food habits. J. Wildl. Manage. 39(2):402-407.

Distel, R. A. 1987. Crecimiento aéreo y radical, germinación y supervivencia en Piptochaetium napostaense (Speg.) Hack y Stipa tenuis Phil (In Spanish). M. S. Thesis, Univ. Nac. del Sur, Bahía Blanca, Argentina.

Distel, R. A. and R. M. Bóo. 1995. Vegetation states and transitions in temperate semiarid rangelands of Argentina. Proceedings of the Vth International Rangeland Congress, Salt Lake City, Utah, USA. 1:117-118.

Distel, R. A. and O. A. Fernández. 1986. Productivity of Stipa tenuis Phil. and Piptochaetium napostaense (Speg.) Hack in semi-arid Argentina. J. Arid Environ. 11:93-96.

Harniss R. O., D. A. Price, and D. C. Tomlin. 1975. Number of fistula samples needed for determination of sheep diet on sagebrushgrass range. J. Range Manage. 28(5):417-419.

Havstad, K. M. and G. B. Donart. 1978. The microhistological technique: testing two central assumptions in South-Central New Mexico. J. Range Manage. 31(6):469-470.

Holechek, J. L. and B. D. Gross. 1982. Training needed for quantifying simulated diets from fragmental range plants. J. Range Manage. 35(6):644-647.

Holechek, J. and R. Valdez. 1985. Magnification and shrub stemmy material influences on fecal analysis accuracy. J. Range. Manage. 38(4):350-352.

Holechek, J., M. Vavra, and R. Pieper. 1982. Botanical composition determination of Range Herbivore Diets: A Review. J. Range Manage. 35(3):309-315.

Lindström, L.I. 1994. Estudio microhistológico de las especies de gramíneas que integran la dieta de vacunos en el caldenal: Elaboración de una clave y su aplicación al análisis de muestras fecales (In Spanish). M.S. Thesis, Univ. Nac. del Sur, Bahía Blanca, Argentina.

Lindström, L. I., M. B. Mújica and L. F. Hernández. 1998a. Descripción microhistológica de dicotiledóneas y gimnospermas del sur del distrito del caldén. (In Spanish). Rev. Arg. Prod. Anim. 18(2):117-128.

Lindström, L. I., M. B. Mújica, and R. M. Bóo. 1998b. A key to identify perennial grasses in central Argentina based on microhistological characteristics. Can. J. Bot. 76: 1467-1475.

Peláez, D.V. 1986. Análisis de algunos factores ambientales y morfológicos y su relación con la aplicación de herbicidas en cinco especies arbustivas del distrito fitogeográfico del Caldén (In Spanish). M.S. Thesis, Univ. Nac. del Sur, Bahía Blanca, Argentina.

Snedecor, G. W. 1956. Statistical methods. $5^{\text {th }}$ ed. Iowa Sta. Univ. Press Ames, Iowa, U.S.A. 503 pp.

Snedecor, G. W. and W. G. Cochran. 1980. Statistical methods. $7^{\text {th }}$ ed. Iowa Sta. Univ. Press Ames, Iowa, U.S.A. 507 pp.
Sparks, D.L. and J.C. Malechek. 1968. Estimating percentage dry weight in diets using a microscopic technique. J. Range. Manage. 21(4):264-265.

Vavra, M. and J. L. Holechek. 1980. Factors influencing microhistological analysis of herbivore diets. J. Range Manage. 33(5): 371-374. 